\title{
Macro and micro effects
} of fiscal policy experience from the COVID-19 pandemic: introduction to the thematic issue of Public Sector Economics

MILAN DESKAR-ŠKRBIĆ, Ph.D.*

DARJAN MILUTINOVIĆ, MA*

Guest Editors' Introduction

https://doi.org/10.3326/pse.45.4.1

\footnotetext{
*Milan DESKAR-ŠKRBIĆ

Croatian National Bank, Trg hrvatskih velikana 3, 10000 Zagreb, Croatia e-mail: mdeskar@hnb.hr

ORCiD: 0000-0002-7611-2071

Darjan MILUTINOVIĆ

Croatian National Bank, Trg hrvatskih velikana 3, 10000 Zagreb, Croatia e-mail: dmilutinovic@hnb.hr ORCiD: 0000-0001-5010-7437
} 
Fiscal policy has taken centre stage in stabilizing economies hit by the pandemic shock in 2020 and 2021. Most governments responded to the disruptions caused by Covid-19 with various above-the-line measures (e.g., large expansion of health-related and other public expenditures and revenue deferrals), directly affecting economic activity via fiscal multipliers, and with below-the-line measures (e.g., equity injections, liquidity loans, debt assumptions) and guarantees, whose economic impact depended on how much they have been taken up and spent by targeted recipients. With respect to EU countries, total fiscal support to the economy from the beginning of the pandemic has ranged from around $7 \%$ of GDP in Croatia to above $45 \%$ in Italy (figure 1). If one focuses only on direct, above-the-line measures, these figures still indicate heavy fiscal support, ranging from $3.5 \%$ of GDP in Denmark to above $20 \%$ in Greece.

\section{Figure 1}

Summary of fiscal measures in response to the Covid-19 pandemic from February 2020 to July 2021 (percentage of 2020 GDP)

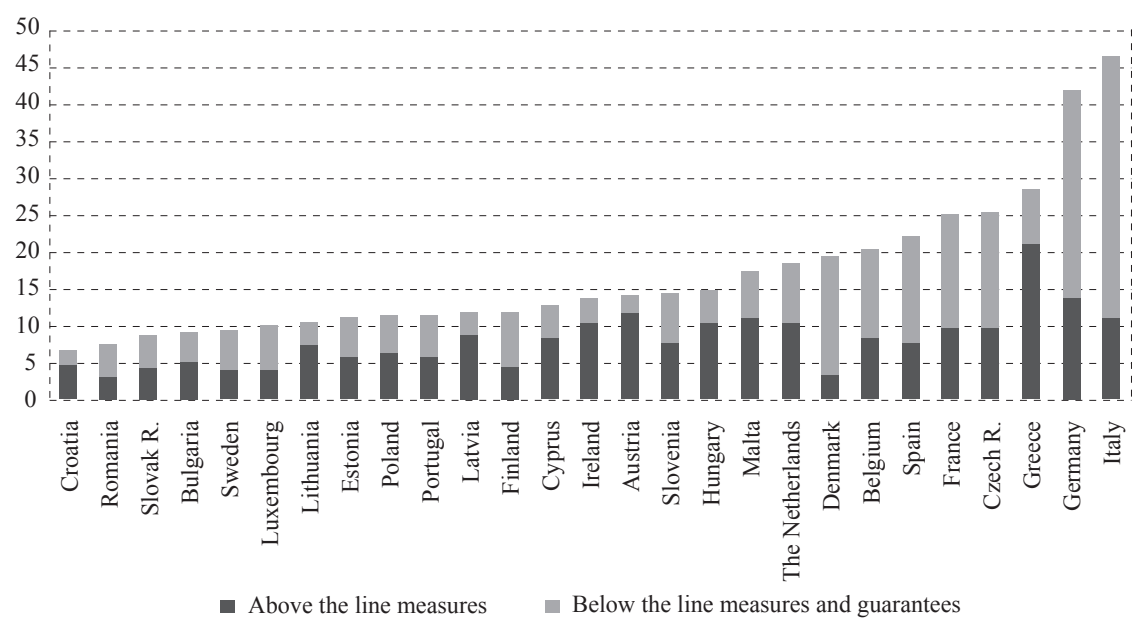

Source: IMF Fiscal Policies Database.

The fiscal response to the Covid pandemic has demonstrated that it is possible to quickly mobilize this powerful stabilisation policy tool and deploy it effectively in the face of a major exogenous shock, despite the well-known procedural challenges related to fiscal policymaking in parliamentary democracies. Active use of fiscal policy has also greatly relieved pressure on monetary policy, which had been "the only game in town" from the start of the Global Financial Crisis (GFC) until the pandemic. It is worth noting that central banks have also given strong support to fiscal authorities and economies in general through asset purchases programs, launched in some countries for the first time. In this context, many authors agree that the Covid-19 crisis represents a great example of adequate monetary-fiscal policy mix (e.g., Ubide, 2021; Buti and Messori, 2021). 
Although discretionary fiscal measures and automatic stabilizers cushioned the adverse economic effects of the Covid-19 shock, they have also led to a sharp increase in public debt, in both absolute and relative terms. Figure 2 shows that in most European countries the increase in public debt in 2020 was much more intense than during the GFC in 2008-09 or the sovereign debt crisis in 2010-12, due to both stronger fiscal reaction and a more substantial fall in GDP. The pandemic has also put intense pressures on healthcare systems around Europe, revealing many structural deficiencies and putting an additional burden on mid-term fiscal sustainability (OECD, 2020).

\section{Figure 2}

\section{Change in public debt-to-GDP ratio in pp of GDP}

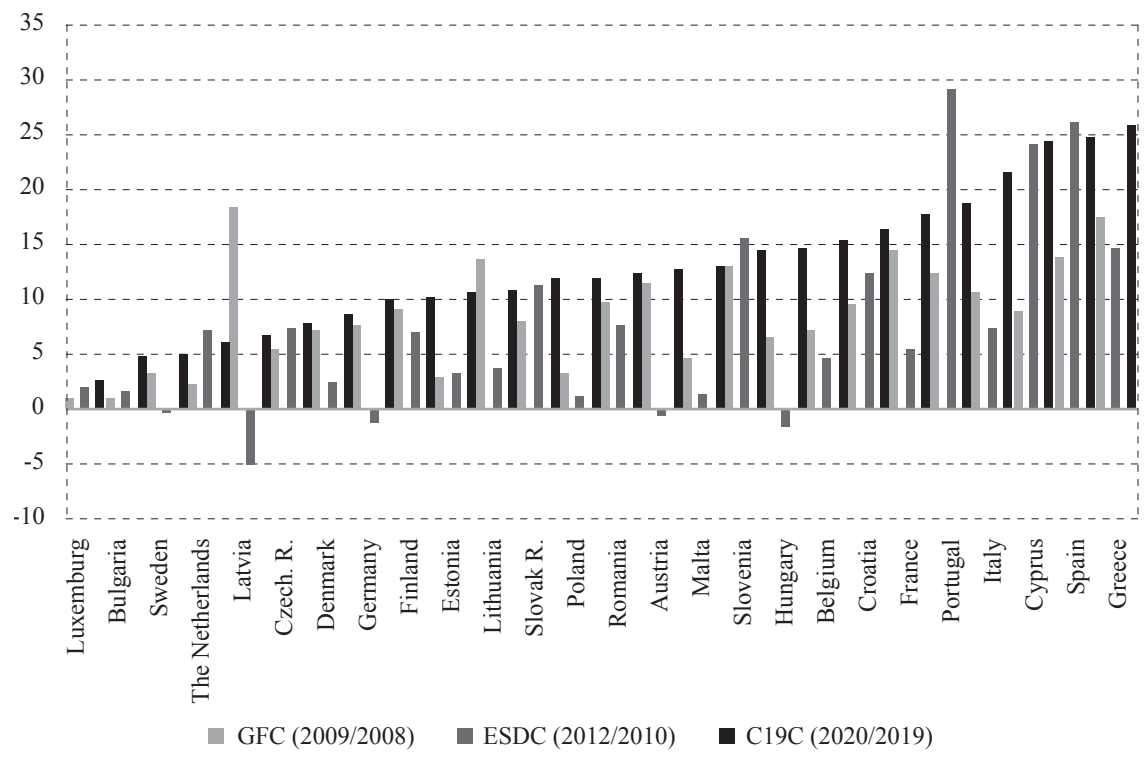

Source: Eurostat; authors' calculations.

To facilitate national fiscal responses to the pandemic shock, EU policymakers used the flexibility of European fiscal rules under the Stability and Growth Pact (SGP) and activated the so-called general escape clause in 2020. As most EU economies are expected to return to pre-pandemic output levels by end-2022, fiscal rules will most likely be re-activated in 2023. At the same time, discussions are underway to reform the EU fiscal rules and facilitate a gradual return to debt sustainability through growth-friendly fiscal consolidation programs. Fiscal policy is thus expected to stay in the focus of policymakers, academic researchers and media in both the EU and in the rest of the World.

Against this background, we launched in early 2021 a call for papers for this special issue of Public Sector Economics. We selected six papers that provide a solid analytical background for discussions on the economic and fiscal effects of the pandemic recession and provide insights and policy recommendations that could 
inform discussions on future developments. The papers cover the economic and fiscal effects of the pandemic on income distribution, analyse the fiscal response, sustainability of healthcare systems, the effects on potential GDP, and changes in the monetary-fiscal policy mix. One common message of these contributions is that this crisis reminded us all that fiscal policy matters. Not only did fiscal policy measures mitigate the short-term effects of the Covid-19 shock but they also ensured that the long term potential of economies is not significantly shattered. However, several papers in this issue indicate that the issue of fiscal sustainability will come back to the table of policy makers really soon. This holds for specific sectors, such as healthcare for example, and for the public sector as a whole.

Dubravko Mihaljek tackles a very topical issue of the monetary-fiscal policy mix in Interactions between monetary and fiscal policies: a brief history of a long relationship. He compares and contrasts the policy mix in major economies during the pandemic recession with selected episodes from the past, notably the Great Inflation of the 1970s, the Great Moderation of the 1990s, and the Great Financial Crisis and its aftermath. The paper highlights the lack of consensus about the proper roles of monetary and fiscal policies during the Great Inflation and since the Great Financial Crisis, and the return of the fiscal stabilisation function in the pandemic recession noted above. Looking ahead, however, consensus on a "new normal" for monetary and fiscal policy mix is unlikely to emerge in the near term, as in the process of policy normalisation the two could at times work at cross purposes.

Vladimir Arčabić and Frane Banić analyse fiscal policy cyclicality and debt sustainability in their paper Characteristics of fiscal policy in Croatia: does it depend on the phase of the business cycle? The authors find evidence of asymmetric fiscal policy stances: in an expansionary regime, fiscal policy is countercyclical, while in a recessionary regime it alternates between a procyclical and an acyclical stance. In the expansionary regime, fiscal policy thus facilitates debt sustainability, while in the recessionary regime its effects are uncertain, although there is clear evidence that debt sustainability worsens.

In The interplay of supply and demand shocks: measuring potential output in the Covid-19 pandemic, Lovorka Grgurić, Nina Pavić and Ozana Nadoveza-Jelić show that the pandemic affected both the supply and the demand sides of the Croatian economy. Protective measures imposed unprecedented supply-side restrictions, while uncertainty about the course of the pandemic affected domestic and foreign demand, notably in tourism. Estimating potential GDP, which is difficult in stable economic conditions, was a major challenge as a result. The authors provide several methodological approaches and conclude that in 2020 there was a significant decline in potential GDP in Croatia accompanied by a record large negative output gap. Such developments indicate that the Covid-19 shock has spilled over to the Croatian economy through both supply side and demand side channels. Thus, the authors call for the strong expansionary measures that are 
necessary condition for stabilizing the economy and its faster recovery, not only in the short, but probably also in the medium term.

In Fiscal (un)sustainability of the Croatian healthcare system: additional impact of the Covid-19 crisis, Hrvoje Šimović, Maja Mihelja Žaja and Marko Primorac note that the Covid-19 crisis deepened and exacerbated the already existing financing problems of the Croatian healthcare system. They estimate the cost of public bailouts of the system at more than HRK 23 billion (around 6\% of 2020 GDP) in 1994-2021. Nevertheless, the authors see the Covid-19 crisis as a chance to start solving the problems by implementing reforms on both the revenue and the expenditure sides of the healthcare system.

In The impact of the Covid-19 crisis on income distribution under different protection schemes: the case of Spain, Gonzalo Gomez-Bengoechea uses household survey data to estimate the costs of lockdowns under three different protection schemes for low-income earners: no low income benefit scheme, direct meanstested transfer from regional governments to households and national-wide means-tested program. His results show that although the pandemic shock reduced income for all deciles of the income distribution, the losses were not uniformly distributed. The worst economic effects have not been on the poorest households in the ex-ante income distribution, but on middle-income and wealthy households. Low-income households have experienced only moderate income losses owing to the fiscal measures aimed at the reduction of poverty and inequality.

Teboho Jeremiah Mosikari and Joel Hinaunye Eita focus on the relationship between public indebtedness and economic growth in their paper Asymmetric effect of government debt on economic growth: evidence from Namibia. They show that an increase in government debt is associated with slower GDP growth and vice versa - a decrease in debt helps raise GDP growth. Importantly, these effects are asymmetric: the harmful effect of higher debt on growth is greater than the marginal boost to growth from debt reductions. They conclude that, to accelerate GDP growth, it is important for Namibia to keep public debt at manageable levels and achieve fiscal sustainability. This conclusion probably holds for many other countries as well.

As the Guest Editors of this special issue, we would like to thank the authors for finding time in these exceptional circumstances to send us very interesting and analytically rich papers. We are also grateful to the reviewers for their patient reading and rich and helpful feedback, and to the great team from the Institute of Public Finance - Mihaela Bronić and Branko Stanić. Finally, we are especially grateful to Katarina Ott for giving us the opportunity to arrange this special issue. Almost 20 years ago, Bob Solow (2004) posed two big questions: Is fiscal policy possible? Is it desirable? We hope that this issue of Public Sector Economics shows that the answer to both questions is a resounding "YES!" 
1. Buti, M. and Messori, M., 2021. Euro Area policy mix: from horizontal to vertical coordination. CEPR Policy Insight, No. 113.

2. IMF, 2020. IMF Fiscal Monitor. Washington: International Monetary Fund.

3. OECD/European Union, 2020. Health at a Glance: Europe 2020: State of Health in the EU Cycle. Paris: OECD. https://doi.org/10.1787/82129230-en

4. Solow, R. M., 2004. Is fiscal policy possible? Is it desirable? In: R. M. Solow, ed. Structural Reform and Economic Policy. London: Palgrave Macmillan, pp. 23-39.

5. Ubide, A., 2021. An all-weather economic policy framework for the euro area. VoxEu column, October 8, 2021. 